\title{
IMPLIKASI PENGARUH KINERJA DAN KEPUASAN KERJA SERTA KOMITMEN KEORGANISASIAN TERHADAP IKLIM ORGANISASI SEKRETARIAT DPRD DI SUMATERA SELATAN
}

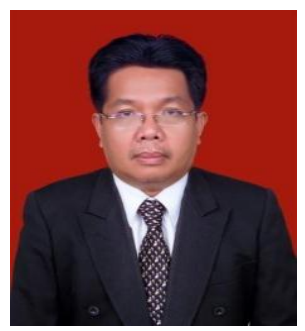

\author{
Fakhry Zamzam \\ Dosen Magister Manajemen UIGM Palembang \\ Email : fakhry@uigm.ac.id
}

Tujuan Penelitian untuk mengkaji pengaruh kinerja, kepuasan kerja dan komitmen keorganisasian terhadap iklim organisasi pada Sekretariat DPRD di Sumatera Selatan. Persoalan iklim organisasi pada Sekretariat DPRD menarik dikaji lebih mendalam, karena berkaitan dengan hubungan antara legislasi dan eksekutif.

Penelitian kuantitatif metode survey konfirmatif bersifat deskriptif dan verifikatif. Lokus pada Sekretariat DPRD Provinsi Sumatera Selatan, Kota Palembang, Kabupaten Ogan Komering Ilir, Kabupaten Ogan Ilir dan Kabupaten Banyuasin; analisis data menggunakan instrumen SEM-Listreal dilengkapi dengan SPSS; Penelitian ini dilaksanakan dalam jangka waktu 4 bulan yaitu Maret 2016 sampai dengan September 2016; populasi dan sampel jenuh sebanyak 225 responden pengumpulan data menggunakan kuesioner.

Kinerja berpengaruh positif dan signifikan terhadap kepuasan kerja dengan $\mathrm{T}$ hitung 6,75> 1,96 dengan koefisien 0,87, kinerja memengaruhi iklim organisasi dengan T hitung 4,87 > 1,96 dan koefisien 0,74, kinerja memengaruhi positif dan signifikan komitmen organisasi dengan $\mathrm{T}$ hitung 9,99<1,96 dan kofisien 0,53 , kepuasan kerja tidak berpengaruh terhadap iklim organisasi dengan $\mathrm{T}$ hitung $0,88<1,96$ dan koefisein 0,12 , kepuasan kerja secara positif dan sifnifikan terhadap komitmen organisasi dengan $\mathrm{T}$ hitung 2,96>1,96 dan koefisien 0,32, komitmen organisasi tidak berpenaruh terhadap iklim organisasi dengan $\mathrm{T}$ hitung 0,67 > 1,96 dan koefisein 0,07 dan kinerja, komitmen organisasi dan kepuasan kerja memengaruhi iklim organisasi sebesar $57 \%$. berdasarkan hasil persamaan structural $\mathrm{IO}=0.07 * \mathrm{KO}+0.12 * \mathrm{KK}+0.74 * \mathrm{KJ}+0,43 \mathrm{E}$.

Dari hasil penelitian dapat disusun kerangka strategi dalam manajemen Sekretariat DPRD di Sumatera selatan bahwa "Untuk meningkatkan iklim organisasi pada Sekretariat DPRD Di Sumatera Selatan yang kondusif dengan memberikan penghargaan Dukungan Sekretariat DPRD oleh DPRD, melalui peningkatan kinerja pegawai Sekretariat DPRD yang mampu bekerja dengan prinsip saling mendukung dan melengkapi dalam pelaksanaan tugas.

Kata kunci: Iklim Organisasi, Kinerja, Komitmen Keorganisasian, dan Kepuasan Kerja

\section{A. PENDAHULUAN}

Sekretariat Dewan Perwakilan Rakyat Daerah (DPRD) adalah Perangkat Daerah, secara administratif berada di bawah Kepala Daerah melalui Sekretaris Daerah sedangkan operasionalnya berada langsung di bawah Pimpinan DPRD. Tugas pokok dan fungsi Sekretariat DPRD dalam pasal 123 UU Nomor 32 tahun 2014 adalah ; a. Menyelenggarakan administrasi Sekretariat DPRD, b. Menyelenggarakan administasi keuangan DPRD, c. Mendukung pelaksanakan tugas dan fungsi DPRD, dan d. Menyediakan dan mengkoordinasikan tenaga ahli yang diperlukan oleh DPRD dalam menjalankan fungsi sesuai dengan kemampuan keuangan daerah.

Kedudukan Sekretariat DPRD menjadi penting dan strategis, karena berperan dalam membalanced hubungan Kepala Daerah dan DPRD. Jika hubungan Kepala Daerah dan DPRD berjalan dengan harmonis, maka penyelenggaraan pemerintahan di daerah akan menjadi efektif. Sebaliknya jika hubungan Kepala Daerah dengan DPRD tidak harmonis akan berdampak terhadap pembangunan daerah.

Hubungan kerja legislasi dan eksekutif yang harmonis akan membangun iklim organisasi yang kondusif, suasana kerja 
menjadi nyaman akan mendorong hubungan kerja saling mendukung. Akan tetapi dalam praktek, iklim organisasi pada Sekretariat DPRD tidak memengaruhi secara langsung terhadap kinerja pegawai; begitu juga kinerja pegawai tidak selalu dapat mendorong pegawai untuk meningkatkan kepuasan kerja. Sehingga membuat suasana kerja menjadi tidak nyaman, prestasi kerja pegawai tidak bisa ditingkatkan yang pada gilirannya berdampak terhadap komitmen keorganisasian.

Permasalahan iklim organisasi Sekretariat DPRD menarik untuk diteliti lebih mendalam. Kedudukan Sekretariat DPRD sebagai perangkat daerah dan operasionalnya langsung di bawah Pimpinan DPRD. Akan berpengaruh terhadap kinerja pegawai Sekretariat DPRD. Jika Kepala Daerah menilai Sekretariat DPRD tidak mampu menjalankan misinya maka akan mendapatkan resiko, sebaliknya jika DPRD beranggapan layanan Sekretariat kurang maksimal akan mendapat stigma tidak bisa bekerja. Hal ini dipengaruhi oleh Iklim organisasi pada Sekretariat DPRD yang tidak kondusif, hubungan kerja antara yang tidak harmonis akan berimplikasi terhadap kepuasan kerja pegawai Sekretariat DPRD.

\section{B. PERUMUSAN MASALAH}

Dari identifikasi masalah di atas dapat disusun rumusan masalah penelitian sebagai berikut:

1. Apakah kinerja pegawai berpengaruh terhadap kepuasan kerja?

2. Apakah kinerja pegawai berpengaruh terhadap iklim organisasi?

3. Apakah kinerja pegawai berpengaruh terhadap komitmen keorganisasian?

4. Apakah kepuasan kerja berpengaruh terhadap iklim organiasasi?

5. Apakah kepuasan kerja berpengaruh terhadap komitmen keorganisasian?
6. Apakah komitmen keorganisasian berpengaruh terhadap iklim organisasi?

7. Apakah kinerja, kepuasan kerja dan komitmen keorganisasian secara bersama-sama berpengaruh terhadap iklim organisasi?

\section{OPERASIONAL VARIABEL}

\section{(1)Iklim Organisasi}

Dalam penelitian ini definisi konsepsual variabel Iklim organisasi adalah suasana internal lingkungan suatu organisasi yang dipersepsikan oleh anggota organisasi dan berlangsung secara terus menerus sehingga memengaruhi suasana kerja dalam menjalankan tugas menuju tujuan organisasi.

Variabel iklim organisasi yang digunakan dalam penelitian ini merupakan konstruk latent sehingga untuk operasionalisasinya perlu dijabarkan ke dalam beberapa indikator variabel. Indikator variabel iklim organisasi menurut Robert Stringer (2002) adalah sebagai berikut; (1) struktur, (2) standar, (3) tanggung jawab, (4) penghargaan, dan (5) dukungan

Kisi-kisi variabel iklim organisasi dalam penelitian menggunakan 10 indikator seperti yang dapat dilihat dalam tabel berikut ini :

Tabel 1 Kisi-kisi Variabel Iklim

Organisasi

\begin{tabular}{|l|l|c|}
\hline \multicolumn{1}{|c|}{ DIMENSI } & INDIKATOR & KODE \\
\hline Struktur $\left(\mathrm{X}_{1.1}\right)$ & Kejelasan Tugas & Io.01 \\
\cline { 2 - 3 } & $\begin{array}{l}\text { Batasan } \\
\text { kewenangan }\end{array}$ & I0.02 \\
\hline Standar $\left(\mathrm{X}_{1.1}\right)$ & Diklat & Io.03 \\
\cline { 2 - 3 } & Kapasitas kerja & Io.04 \\
\hline Tanggung jawab & Prestasi & Io.05 \\
\cline { 2 - 3 }$\left(\mathrm{X}_{1.2}\right)$ & Apresiasi & Io.06 \\
\hline $\begin{array}{l}\text { Penghargaan } \\
\left(\mathrm{X}_{1.3}\right)\end{array}$ & Berinovasi & Io.07 \\
\cline { 2 - 3 } Dukungan $\left(\mathrm{X}_{1.4}\right)$ & Apresiasi & Io.08 \\
\cline { 2 - 3 } & Dukungan & Io.09 \\
\cline { 2 - 3 } & Hubungan Kerja & Io.10 \\
\hline
\end{tabular}

Sumber : Robert Stringer (2002) 
Tabel 2 Kisi-kisi Variabel Komitmen Keorganisasian

\begin{tabular}{|c|c|c|}
\hline DIMENSI & INDIKATOR & KODE \\
\hline \multirow{3}{*}{$\begin{array}{l}\text { Penerimaan } \\
\text { terhadap tujuan } \\
\text { organisasi(X2.1) }\end{array}$} & $\begin{array}{l}\text { Bekerja saling } \\
\text { menguatkan }\end{array}$ & Ko.01 \\
\hline & Bertanggungjawab & Ko.02 \\
\hline & Memiliki jiwa korsa & Ko.03 \\
\hline \multirow{3}{*}{$\begin{array}{l}\text { Keinginan untuk } \\
\text { bekerja keras } \\
(\mathrm{X} 2.2)\end{array}$} & $\begin{array}{l}\text { Mendahulukan } \\
\text { kepentingan luas }\end{array}$ & Ko.04 \\
\hline & Bekerja keras & Ko.05 \\
\hline & Tanpa kenal lelah & Ko.06 \\
\hline \multirow{3}{*}{$\begin{array}{l}\text { Hasrat untuk } \\
\text { bertahan sebagai } \\
\text { Bagian organisasi }\end{array}$} & $\begin{array}{l}\text { Mencintai } \\
\text { pekerjaan }\end{array}$ & Ko.07 \\
\hline & $\begin{array}{l}\text { Bertahan dalam } \\
\text { pekerjaan }\end{array}$ & Ko.08 \\
\hline & $\begin{array}{l}\text { Tidak berbuat } \\
\text { tercela }\end{array}$ & Ko.09 \\
\hline
\end{tabular}

Sumber :Newstroom (1989)

Tabel 3 Kisi-Kisi Variabel Kinerja

\begin{tabular}{|c|c|c|}
\hline DIMENSI & INDIKATOR & KODE \\
\hline \multirow[t]{2}{*}{ Quality $\left(Y_{1.1}\right)$} & Bekerja terukur & $\mathrm{Kj} .01$ \\
\hline & $\begin{array}{ll}\text { Jaminan mutu } \\
\text { kerja }\end{array}$ & $\mathrm{Kj} . \mathrm{O} 2$ \\
\hline \multirow[t]{2}{*}{ Quantity $\left(Y_{1.2}\right)$} & $\begin{array}{l}\text { Target dan } \\
\text { realisasi kerja }\end{array}$ & Kj.03 \\
\hline & $\begin{array}{l}\text { Penyelesaian } \\
\text { pada waktunya }\end{array}$ & $\mathrm{Kj} .04$ \\
\hline \multirow[t]{2}{*}{ Timeliness $\left(Y_{1.3}\right)$} & $\begin{array}{l}\text { Selesai pada } \\
\text { waktunya }\end{array}$ & $\mathrm{Kj} 05$ \\
\hline & $\begin{array}{l}\text { Tidak persoalkan } \\
\text { waktu }\end{array}$ & Kj.06 \\
\hline \multirow[t]{2}{*}{$\begin{array}{l}\text { Cost } \\
\text { Efectivity }\left(Y_{1.4}\right)\end{array}$} & $\begin{array}{l}\text { Sesuai dengan } \\
\text { beban kerja }\end{array}$ & Kj.07 \\
\hline & $\begin{array}{ll}\text { biaya } & \text { yang } \\
\text { memadai } & \end{array}$ & Kj.08 \\
\hline \multirow[t]{2}{*}{$\begin{array}{l}\text { Need For } \\
\text { Supervision }\left(Y_{1.5}\right)\end{array}$} & $\begin{array}{ll}\text { tidak } & \text { butuh } \\
\text { konselor } & \\
\end{array}$ & Kj.09 \\
\hline & $\begin{array}{ll}\text { tidak } & \text { perlu } \\
\text { petunjuk } & \\
\end{array}$ & $\mathrm{Kj} .1 \mathrm{O}$ \\
\hline \multirow{2}{*}{$\begin{array}{l}\text { Impersonal Impact } \\
\left(Y_{1.6}\right)\end{array}$} & suasana kerja & $\mathrm{Kj} .11$ \\
\hline & Hubungan kerja & $\mathrm{Kj} .12$ \\
\hline
\end{tabular}

Sumber : Bernardin and Russel (1993)

(2) Kepuasan Kerja

Dengan demikian kepuasan kerja berhubungan dengan nilai pekerjaan dan kebutuhan dasar, nilai pekerjaan harus sejalan dengan pemenuhan kebutuhan dasar, sehingga sintesis kepuasan kerja yang diambil dari pendapat para ahli di atas dan akan dijadikan definisi konsepsual penelitian ini. Kepuasan kerja adalah sikap seseorang terhadap pekerjaannya yang berhubungan persepsi dan penilaian terhadap situasi lingkungan kerja, hubungan kerja dan harapan seseorang.

Variabel kepuasan kerja merupakan konstruk latent atau unobserved, sehingga operasionalisasinya perlu dijelaskan oleh beberapa dimensi dan indikator variabel. Indikator variabel kepuasan meliputi; (1) Faktor Individu pekerja, dan (2) Faktor pekerjaan. Kisi-kisi variabel kepuasan kerja terdiri 6 pernyataan seperti dalam tabel berikut :

\section{Tabel 4 Kisi-Kisi Variabel Kepuasan Kerja}

\begin{tabular}{|c|c|c|}
\hline DIMENSI & INDIKATOR & KODE \\
\hline \multirow{4}{*}{$\begin{array}{l}\text { Faktor } \\
\text { Individu } \\
\text { Pekerja } \\
\left(\mathbf{Y}_{2.1}\right)\end{array}$} & Orientasi kerja & Kk.01 \\
\hline & $\begin{array}{l}\text { kecakapan } \\
\text { khusus }\end{array}$ & Kk.02 \\
\hline & $\begin{array}{l}\text { Pengalaman } \\
\text { kerja }\end{array}$ & Kk.03 \\
\hline & $\begin{array}{l}\text { Latar belakang } \\
\text { pendidikan }\end{array}$ & Kk.04 \\
\hline \multirow{3}{*}{$\begin{array}{l}\text { Faktor } \\
\text { Pekerjaan } \\
\left(\mathbf{Y}_{2.2}\right)\end{array}$} & $\begin{array}{l}\text { Kecakapan } \\
\text { khusus }\end{array}$ & Kk.05 \\
\hline & Kedudukan & Kk.06 \\
\hline & $\begin{array}{l}\text { Puas dengan } \\
\text { penghasilan }\end{array}$ & Kk.07 \\
\hline
\end{tabular}

Sumber : Mangkunegara (2009)

\section{METODE PENELITIAN}

Penelitian kuantitatif menggunakan metode survey deskriptif analisis, dengan pendekatan multi disiplin, sehingga landasan teori dan analisis serta 
pembahasan masalah meliputi lintas bidang ilmu, kendati demikian masingmasing bidang ilmu tersebut tetap mempunyai korelasi saling melengkapi.

\section{E. POPULASI DAN SAMPEL}

Populasi penelitian adalah sebanyak 225 pegawai pada Sekretariat DPRD Provinsi Sumatera Selatan, Kota Palembang, Kabupaten Ogan Komering Ilir, Kabupaten Banyuasin dan Kabupaten Ogan Ilir. Seluruh populasi adalah sampel penelitian, teknik sampling menggunakan sampel jenuh.

\section{F. METODE PENELITIAN}

Penelitian kuantitatif menggunakan metode survey deskriptif analisis, dengan pendekatan multi disiplin, sehingga landasan teori dan analisis serta pembahasan masalah meliputi lintas bidang ilmu, kendati demikian masingmasing bidang ilmu tersebut tetap mempunyai korelasi saling melengkapi.

\section{G. POPULASI DAN SAMPEL}

Populasi penelitian adalah sebanyak 225 pegawai pada Sekretariat DPRD Provinsi Sumatera Selatan, Kota Palembang, Kabupaten Ogan Komering Ilir, Kabupaten Banyuasin dan Kabupaten Ogan Ilir. Seluruh populasi adalah sampel penelitian, teknik sampling menggunakan sampel jenuh.

\section{Tabel 5 Populasi Dan Sampel Penelitian}

\begin{tabular}{|c|l|c|}
\hline No & $\begin{array}{c}\text { SEKRETARIAT } \\
\text { DPRD }\end{array}$ & POPULASI/SAMPLE \\
\hline 1 & Provinsi Sumsel & 61 \\
\hline 2 & Kota Palembang & 53 \\
\hline 3 & Kabupaten OKI & 56 \\
\hline 4 & Kabupaten Ogan Ilir & 32 \\
\hline 5 & $\begin{array}{l}\text { Kabupaten } \\
\text { Banyuasin }\end{array}$ \\
\hline \multicolumn{2}{|c|}{ Jumlah } & 23 \\
\hline
\end{tabular}

Sumber : Sekretariat DPRD Diolah, 2016

\section{H. KERANGKA PEMIKIRAN}

Peningkatan kinerja pegawai akan dapat meningkatkan kepuasan kerja, pegawai yang memiliki kinerja baik pada umumnya selalu puas atas hasil yang telah dikerjakan dengan baik.

Peningkatan kinerja pegawai dapat memengaruhi iklim organisasi, kinerja pegawai yang tinggi akan bekerja dalam tugas dan pada gilirannya dapat meningkatkan iklim organisasi yang saling mendukung.

Peningkatan kinerja dapat memengaruhi peningkatan komitmen keorganisasian pegawai, pegawai yang memiliki komitmen keorganisasian tinggi selalu akan meningkatkan kinerjanya

Peningkatan kepuasan kerja akan memengaruhi iklim organisasi. Pegawai yang telah puas dalam bekerja, akan selalu memmbangun komunikasi yang baik dengan pekerja yang lain. Sehingga suasana kerja menjadi nyaman dan kondusif

Peningkatan kepuasan kerja memengaruhi peningkatan komitmen keorganisasian pegawai. Pegawai yang telah meningkatkan kepuasan kerjanya akan dapat meningkatkan komitmennya terhadap organisasi, seperti tidak ingin pindah pada organisasi lain,

Peningkatan komitmen keorganisasian akan memengaruhi iklim organisasi, jika pegawai memiliki komitmen yang kuat terhadap organisasi. Maka pegawai akan dapat bekerja secara nyaman, mampu bekerja dengan pegawai yang lain.

Peningkatan kinerja, kepuasan kerja dan komitmen keorganisasian secara bersamasama memengaruhi peningkatan iklim organisasi. Iklim organisasi akan dapat meningkat apa bila kinerja meningkat, kepuasan kerja meningkat dan komitmen keoarganisasian juga meningkat. 
Kerangka pemikiran penelitian di atas dapat digambarkan ke dalam bagan alir pikir sebagai dalam gambar di bawah ini,

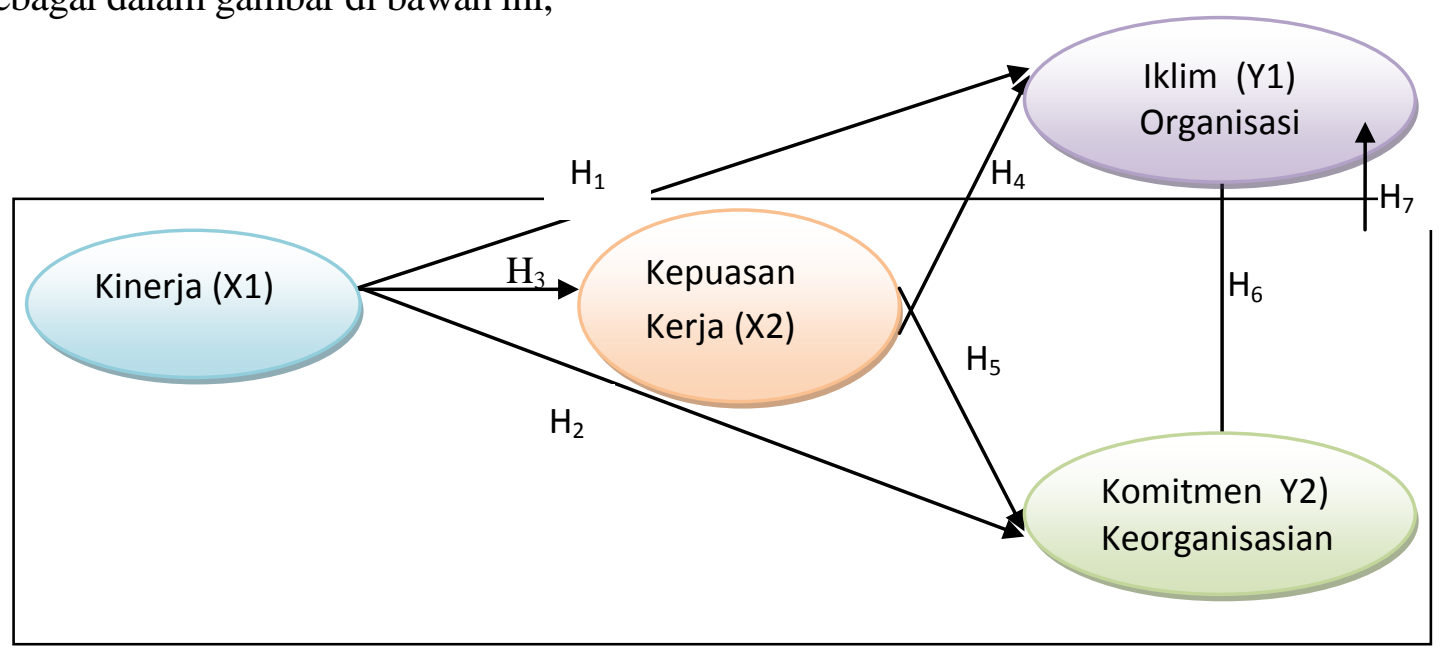

Gambar 1 Bagan Alir Pikir Penelitian

\section{RANCANGAN ANALISIS}

Tehnik analisis data yang digunakan dalam penelitian ini menggunakan tehnik analisis data kuantitatif didukung dengan analisis data kualitatif yang memiliki keunggulan dan kelemahan namun akan dapat saling melengkapi.

\section{1) Analisis Kualitatif}

Analisis kualitatif dimanfaatkan guna menganalisis data primer yang telah dikumpulkan dari penyebaran Kuesioner, wawancara. Pada pembahasan hasil-hasil analisis kuantitatif serta melakukan perbandingan dengan hasil-hasil penelitian sebelumnya.

\section{2) Analisis Kuantitatif}

Analisis kuantitatif yang merupakan analisis statistika dalam penelitian tesis ini menggunakan analisis statistika deskriptif san statistika inferensial sebagai berikut;

\section{(1)Analisis Statistika Deskriptif}

Analisis statistika deskriptif menggunakan perangkat SPSS untuk mendeskripsikan variabel penelitian pada lokus penelitian. Untuk mendapat gambaran dimensi dan indikator Variabel yang dominan.
(2)Analisis Statistika Inferensial

Analisis statistika inferensial menggunakan perangkat SEM-Amos untuk menganalisis hubungan antara variabel eksogen terhadap endogen. Pengaruh langsung atau pengaruh tidak langsung eksogen terhadap endogen. Serta mendapatkan persamaan struktural.

\section{J. ANALISIS STATISTIKA DESKRIPTIF}

Persepsi responden terhadap iklim organisasi pada Sekretariat DPRD sudah baik dengan koefisien 3,13 pada skala 1 sampai dengan 4. Jawaban responden tertinggi pada indikator IO.10 Yaitu Dukungan Sekretariat DPRD dihargai oleh DPRD dengan koefisein sebesar 3.31.

Persespsi responden terhadap komitmen keorganisasian pegawai Sekretariat DPRD telah baik dengan koefisien rata-rata 3,12 keadaan ini masih bisa dimaksimal agar dipertahankan. Indikator dominan adalah KO.02 yaitu Sekretariat DPRD berkomitmen menjaga kehormatan DPRD dengan koefisien sebesar 3,25. 
Persepsi responden terhadap kinerja Sekretariat DPRD agak baik dengan koefisien rata-tara sebesar 2,97 keadaan ini masih bisa ditingkatkan secara maksimal dan indikator dominan yang mendapat koefisien tertinggi adalah $\mathrm{Kj} .12$ yaitu Pegawai Sekretariat DPRD saling dukung dalam tugas dengan koefisein sebesar 3.19

Persepsi responden terhadap kepuasan kerja pegawai Sekretariat DPRD cukup baik dengan koefisein rata-rata sebesar 2,94 kondisi ini dapat ditingkatkan. Indikator pada variabel kepuasan kerja dominan dominan adalah KK.06 yaitu Pegawai Sekretariat DPRD bangga dengan jabatannya dengan koefisien sebesar 3.13.

\section{K. PENGUJIAN ASUMSI KLASIK}

Penelitian ini menggunakan skala interval, data skala likert untuk analisis dalam penelitian ini telah memenuhi persyaratan Asumsi Structural Equation Modelling (SEM).

Jumlah populasi dan sampel penelitian adalah sebanyak 225 responden,teknik sampling menggunakan teknik sensus atau jenuh. Jumlah sampel penelitian ini sudah memenuhi ketentuan minimal (minimum requirement).

Pengujian normalitas data dilakukan dengan mengamati nilai skewness dan kurtosis data yang digunakan, apabila nilai p-value dari statistik Chi-Square $>5 \%$, maka data dapat disimpulkan berdistribusi normal. Multicollinearity Jika nilai VIF lebih kecil dari 10 maka tidak terdapat multikolinieritas. Hasil nilai VIF dalam penelitian ini telah memenuhi Multicollinearity

\section{ANALISIS SEM}

Analisis selanjutnya adalah analisis Structural Equation Modelling (SEM) secara full model (tanpa melibatkan indikator yang tidak valid). Analisis hasil pengolahan data pada tahap full model SEM dilakukan dengan melakukan uji kesesuaian dan uji statistik.

Untuk menguji kelayakan model secara keseluruhan (Ful Model) dilakukan dengan memperhatikan hasil perhitungan Goodness of Fit Statistics dengan Software LISREL 8.8. Adapun pengujiannya merujuk pada kriteria model fit yang terdapat pada tabel Goodness Of Fit Index berikut:

Tabel 6 Goodness Of Fit Index

\begin{tabular}{|c|c|c|c|c|c|}
\hline No & Goodness Of Fit Index & Nilai & Cut off Value (Nilai Batas) & Kriteria & Keterangan \\
\hline \multirow{2}{*}{1.} & Chi-Square & 962.61 & $<\boldsymbol{\alpha . d f}$ & \multirow{2}{*}{ Good Fit } & \multirow{2}{*}{ Tidak Fit } \\
\hline & Probability & 0,000 & $>0,05$ & & \\
\hline 2. & RMSEA & 0,000 & $\begin{array}{c}\leq 0,08 \\
0,08-0,10\end{array}$ & $\begin{array}{c}\text { Good Fit } \\
\text { Marginal Fit }\end{array}$ & Fit \\
\hline 3. & NFI & 0,79 & $\begin{array}{c}\geq 0,90 \\
0,80-0,89\end{array}$ & $\begin{array}{c}\text { Good Fit } \\
\text { Marginal Fit }\end{array}$ & Tidak Fit \\
\hline 4. & TLI atau NNFI & 0,86 & $\begin{array}{c}\geq 0,90 \\
0,80-0,89\end{array}$ & $\begin{array}{c}\text { Good Fit } \\
\text { Marginal Fit }\end{array}$ & Fit \\
\hline 5. & CFI & 0,87 & $\begin{array}{c}\geq 0,90 \\
0,80-0,89\end{array}$ & $\begin{array}{c}\text { Good Fit } \\
\text { Marginal Fit }\end{array}$ & Fit \\
\hline 6. & IFI & 0,87 & $\begin{array}{c}\geq 0,90 \\
0,80-0,89\end{array}$ & $\begin{array}{c}\text { Good Fit } \\
\text { Marginal Fit }\end{array}$ & Fit \\
\hline 7. & RMR & 0,026 & $\begin{array}{c}\leq 0,05 \\
0,05-0,10\end{array}$ & $\begin{array}{l}\text { Good Fit } \\
\text { Marginal Fit }\end{array}$ & Fit \\
\hline 8. & GFI & 0,77 & $\begin{array}{c}\geq 0,90 \\
0,80-0,89\end{array}$ & $\begin{array}{c}\text { Good Fit } \\
\text { Marginal Fit }\end{array}$ & Tidak Fit \\
\hline 9. & AGFI & 0,73 & $\begin{array}{c}\geq 0,90 \\
0,80-0,89\end{array}$ & $\begin{array}{c}\text { Good Fit } \\
\text { Marginal Fit }\end{array}$ & Tidak Fit \\
\hline
\end{tabular}

Sumber : Ghozali (2008) dan Data Penelitian diolah, 2016 
Hasil analisis Lisrel di atas menunjukkan bahwa model secara keseluruhan (Ful Model) mempunyai lima kriteria goodness of fit yang memenuhi. Menurut Hair et al. (2010) Penggunaan 4-5 Kriteria goodness of fit dianggap sudah mencukupi untuk menilai kelayakan model. Model secara keseluruhan (Ful Model) yang dihasilkan sudah mempunyai goodness of fit yang cukup, dan dapat dilanjutkan dalam analisis selanjutnya. Hasil pendugaan untuk analisis full model SEM berdasarkan t-value ditampilkan pada Gambar berikut :

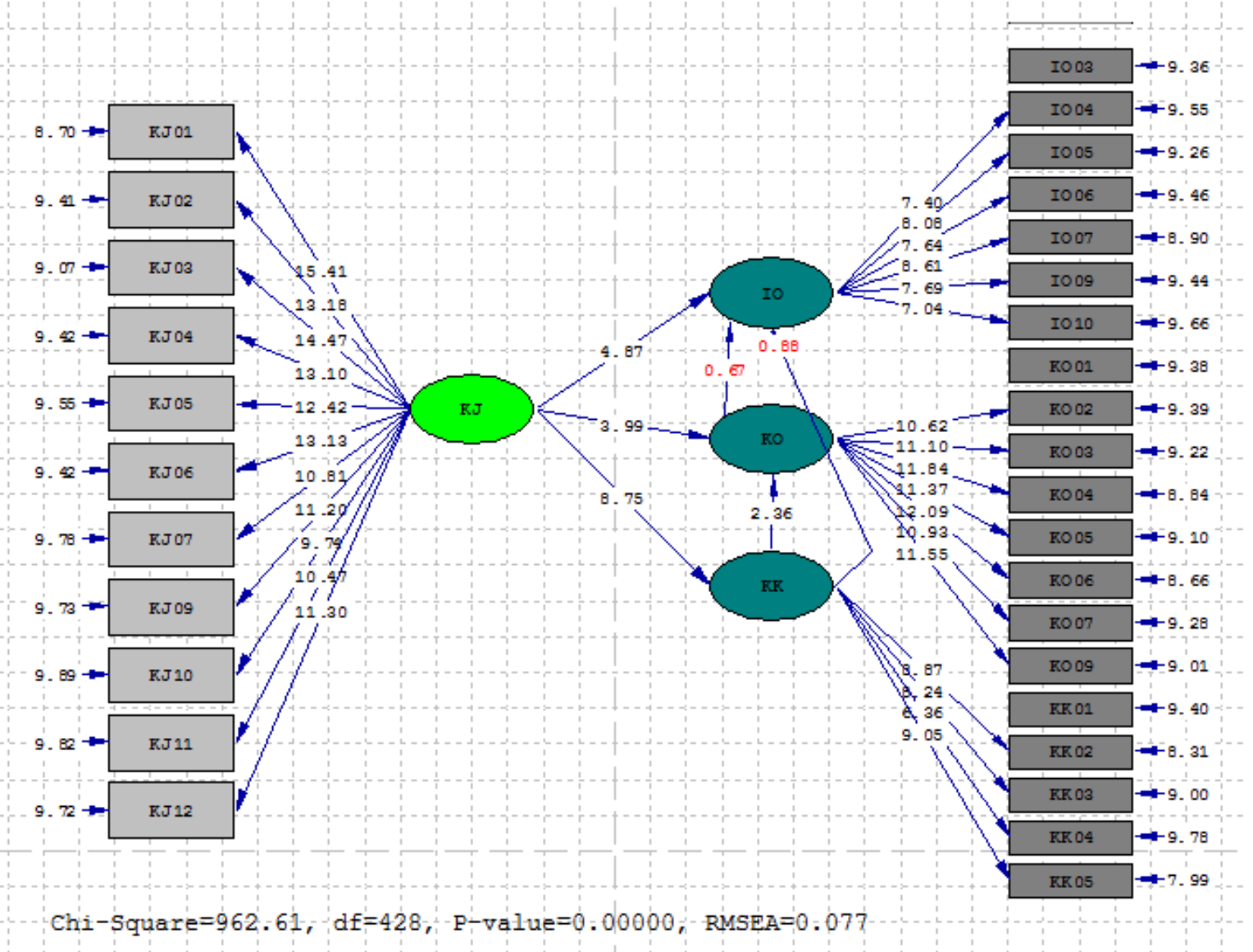

Gambar 2 Hasil Pendugaan Full Model berdasarkan t-value

Gambar di atas diketahui bahwa hampir semua parameter pada Full Model seluruhnya signifikan (nilai t-hitung yang lebih besar dari 1,96), kecuali untuk pengaruh Komitmen Organisasi terhadap Kinerja dan Kepuasan Kerja yang tidak signifikan pada taraf 5\%, serta pengaruh Iklim Organisasi terhadap Produktivitas. Hasil pendugaan untuk analisis full model SEM berdasarkan standar loading ditampilkan pada Gambar berikut : 


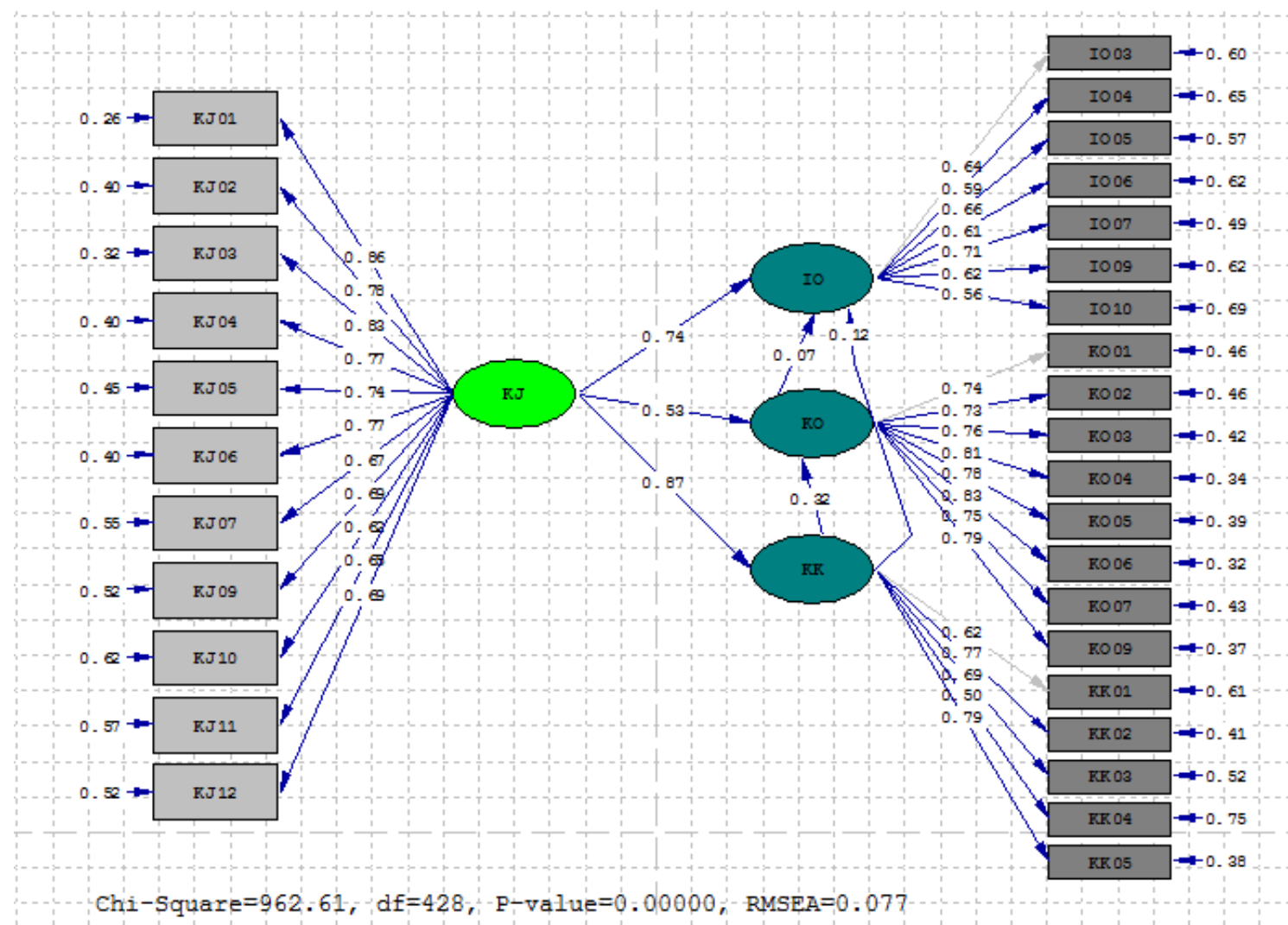

Gambar 3 Hasil Pendugaan Full Model berdasarkan Standar Loading

Dari gambar di atas, diperoleh Persamaan Struktural yaitu IO $=0.07 * \mathrm{KO}$ $+0.12 * \mathrm{KK}+0.74 * \mathrm{KJ}+\mathrm{E}$. Model struktural di atas dapat menjelaskan bahwa iklim organisasi dipengaruhi secara bersamasama oleh komitmen keorganisasian, kepuasan kerja dan kinerja msing-masing sebesar 0,07, 0,12 dan om74 Hal tersebut menunjukan bahwa jika kinerja semakin baik maka iklim organisasi juga akan semakin meningkat lebih baik pada taraf kepercayaan $95 \%$.

\section{Pengaruh Langsung dan Tidak Langsung}

Analisis pengaruh ditujukan untuk melihat seberapa kuat pengaruh suatu variabel dengan variabel lainnya baik secara langsung, maupun secara tidak langsung. Interpretasi dari hasil ini akan memiliki arti yang penting untuk menentukan strategi yang jelas dalam rangka meningkatkan kinerja. Hasil perhitungan pengaruh langsung dan tidak langsung oleh LISREL adalah sebagai berikut :

Tabel 7 Pengaruh Langsung

\begin{tabular}{|l|c|c|c|}
\hline & Kinerja & $\begin{array}{c}\text { Kepuasan } \\
\text { Kerja }\end{array}$ & $\begin{array}{c}\text { Komitmen } \\
\text { Keorganisasian }\end{array}$ \\
\hline $\begin{array}{l}\text { Kepuasan } \\
\text { Kerja }\end{array}$ & 0,87 & & \\
\hline $\begin{array}{l}\text { Komitmen } \\
\text { Organisasi }\end{array}$ & 0,53 & 0,32 & 0,07 \\
\hline $\begin{array}{l}\text { Iklim } \\
\text { Organissi }\end{array}$ & 0,74 & 0,12 & \\
\hline
\end{tabular}

Sumber: Hasil Olah Data 2016

Dari hasil koefisien korelasi pengaruh langsung pada tabel di atas menunjukkan bahwa;

Pengaruh langsung kinerja terhadap kepuasan kerja, komitmen keorganisasian dan iklim organisasi masing-masing sebesar $87 \%$, 53\% dan 74\%. Pengaruh 
tersebut merupakan pengaruh yang positif dan signifikan, artinya jika kinerja meningkat maka akan meningkatkan kepuasan kerja, komitmen organisasi dan iklim organisasi secara signifikan.

Pengaruh langsung kepuasan kerja terhadap komitmen keorganisasian dan iklim organisasi sebesar $32 \%$ dan $12 \%$. Pengaruh tersebut juga merupakan pengaruh yang positif dan signifikan terhadap komitmen keorganisasian, namun tidak signifikan terhadap iklim organisasi, sehingga jika kepuasan kerja meningkat maka komitmen keorganisasian akan semakin meningkat secara signifikan, namun peningkatan iklim organisasi menjadi tidak signifikan.

Pengaruh langsung komitmen keorganisasian terhadap iklim organisasi sebesar $7 \%$, pengaruh tersebut merupakan pengaruh yang positif namun tidak signifikan, artinya jika komitmen organisasi meningkat maka iklim organisasi akan meningkat, namun peningkatannya tidak signifikan.

\section{Pengaruh Tidak langsung}

Pengaruh tidak langsung untuk melihat pengaruh variabel independen terhadap variabel dependen melalui variabel moderasi, sebagaimana dalam tabel berikut;

Tabel 8 Pengaruh Tidak Langsung

\begin{tabular}{|c|c|c|c|}
\hline & \multicolumn{3}{|c|}{ Kinerja } \\
\cline { 2 - 4 } & $\begin{array}{c}\text { Kepuasan } \\
\text { Kerja }\end{array}$ & $\begin{array}{c}\text { Komitmen } \\
\text { Organisasi }\end{array}$ & $\begin{array}{c}\text { Kepuasan Kerja } \\
\text { dan Komitmen } \\
\text { Organisasi }\end{array}$ \\
\hline $\begin{array}{c}\text { Komitmen } \\
\text { Organisasi }\end{array}$ & 0,278 & & \\
\hline $\begin{array}{c}\text { Iklim } \\
\text { Organisasi }\end{array}$ & 0,104 & 0,037 & 0,02 \\
\hline
\end{tabular}

Sumber: Hasil Olah Data Diolah, 2016
Informasi pengaruh tidak langsung dari tabel di atas dapat dijelaskan adalah sebagai berikut:

Pengaruh tidak langsung dari kinerja melalui kepuasan kerja tehadap Komitmen Organisasi sebesar 0,278, hal ini menunjukkan bahwa pengaruh tidak langsung dari kinerja melalui kepuasan kerja terhadap komitmen keorganisasian lebih kecil daripada pengaruh langsung yang sebesar 0,53. Hal tersebut dapat disimpulkan bahwa kepuasan kerja bukan merupakan variabel perantara yang baik bagi pengaruh kinerja terhadap komitmen keorganisasian.

Pengaruh tidak langsung dari kinerja melalui kepuasan kerja tehadap iklim organisasi sebesar 0,104, hal ini menunjukkan bahwa pengaruh tidak langsung dari kinerja melalui kepuasan kerja terhadap iklim organisasi lebih kecil daripada pengaruh langsung yang sebesar 0,74. Hal tersebut dapat disimpulkan bahwa kepuasan kerja bukan merupakan variabel perantara yang baik bagi pengaruh kinerja terhadap iklim organisasi.

Pengaruh tidak langsung dari kinerja melalui komitmen keorganisasian tehadap iklim organisasi sebesar 0,037, hal ini menunjukan bahwa pengaruh tidak langsung dari kinerja melalui komitmen organisasi tehadap Iklim organisasi lebih kecil daripada pengaruh langsungnya yang sebesar 0,74. Hal tersebut dapat disimpulkan bahwa komitmen organisasi bukan merupakan variabel perantara yang baik bagi pengaruh kinerja terhadap iklim organisasi.

Pengaruh tidak langsung dari kinerja melalui kepuasan kerja dan komitmen keorganisasian tehadap iklim organisasi sebesar 0,02, hal ini menunjukan bahwa pengaruh tidak langsung dari kinerja melalui kepuasan kerja dan komitmen 
keorganisasian secara bersama-sama tehadap iklim organisasi lebih kecil daripada pengaruh langsungnya yang sebesar 0,74. Hal tersebut dapat disimpulkan bahwa kepuasan kerja dan komitmen keorganisasian secara bersamasama bukan merupakan variabel perantara yang baik bagi pengaruh kinerja terhadap iklim organisasi.

\section{KESIMPULAN}

Benang merah yang dapat ditarik sebagai kesimpulan penelitian ini adalah sebagai berikut ;

(1) Hasil pengujian hipotesis bahwa kinerja berpengaruh positif dan signifikan terhadap kepuasan kerja dengan $\mathrm{T}$ hitung 6,75 > 1,96 dengan koefisien 0,97. Dengan demikian hasil penelitian menunjukkan bahwa kinerja memengaruhi kepuasan kerja secara positif dan signifikan.

(2) Hasil pengujian hipotesis bahwa kinerja memengaruhi iklim organisasi dengan $\mathrm{T}$ hitung 4,87>1,96 dan koefisien 0,74. Dengan demikian hasil peneltian menunjukkan bahwa terdapat pengaruh positif dan signifikan terhadap iklim organisasi.

(3) Hasil pengujian hipotesis bahwa kinerja memengaruhi positif dan signifikan komitmen organisasi dengan $\mathrm{T}$ hitung 9,99 $<1,96$ dan kofisien 0,53. Dengan demikian hasil penelitian menunjukkan bahwa terdapat pengaruh kinerja secara positif dan signifikan terhadap komitmen organisasi.

(4) Hasil pengujian hipotesis bahwa kepuasan kerja tidak berpengaruh terhadap iklim organisasi dengan $\mathrm{T}$ hitung 0,88 < 1,96 dan koefisein 0,12. Dengan demikian tidak terdapat pengaruh kepuasan kerja terhadap komitmen organisasi

(5) Hasil pengujian hipotesis bahwa terdapat pengaruh kepuasan kerja secara positif dan sifnifikan terhadap komitmen organisasi dengan $\mathrm{T}$ hitung $2,96>1,96$ dan koefisien 0,32. Dengan demikian hasil penelitian menunjukkan terdapat pengaruh kepuasan kerja terhadap komitmen oragnisasi

(6) Hasil pengujian hipotesis bahwa komitmen organisasi tidak berpenaruh terhadap iklim organisasi dengan $\mathrm{T}$ hitung 0,67 > 1,96 dan koefisein 0,07 Dengan demikian hasil peneltian tidak terdapat pengaruh komitmen organisasi terhadap iklim organisasi.

(7) Hasil pengujian hipotesis bahwa kinerja, komitmen organisasi dan kepuasan kerja memengaruhi iklim organisasi sebesar $57 \%$. berdasarkan hasil persamaan structural $\mathrm{IO}=$ $0.07 * \mathrm{KO}+0.12 * \mathrm{KK}+0.74 * \mathrm{KJ}+0,43 \mathrm{E}$. Dengan demikian hasil peneltian bahwa terdapat pengaruh kinerja, komitmen keorganisasian dan kepuasan kerja secara bersama-sama terhadap iklim organisasi.

\section{N. IMPLIKASI MANAJERIAL}

Dari hasil penelitian dapat disusun kerangka strategi dalam manajemen Sekretariat DPRD di Sumatera selatan bahwa "Untuk meningkatkan iklim organisasi pada Sekretariat DPRD Di Sumatera Selatan yang kondusif dengan memberikan penghargaan Dukungan Sekretariat DPRD oleh DPRD, melalui peningkatan kinerja pegawai Sekretariat DPRD yang mampu bekerja dengan prinsip saling mendukung dan melengkapi dalam pelaksanaan tugas. 


\section{O. REKOMENDASI PENELITIAN}

Penelitian ini memberikan rekomendasi sebagai berikut;

(1) Penelitian lanjutan untuk mengetahi variabel lain yang dapat memengaruhi iklim oraganisai pada Sekretariat DPRD, seperti kompensasi kerja, komunikasi kerja dan kompetensi.

(2) Penelitian lebih lanjut mengenai perencanaan dan pengembangan sumberdaya pada Sekretariat DPRD dalam rangka menghadapi semakin meningkatkan peran dan tanggung jawab DPRD.

(3) Dalam rangka meningkatkan iklim kerja yang kondusif perlu dibangun suasana kerja pada Sekretariat DPRD, sehingga pegawai mampu bekerja sama saling mendukung dan saling melangkapi.

\section{DAFTAR PUSTAKA}

Azwar, S, 2009. Metode Penelitian. Yogyakarta. Penerbit Pustaka Pelajar

Budiman, 2011, Penelitian Kesehatan, Bandung. Penerbit PT. Refika Aditama

Chandra. B, 2008, Metodologi Penelitian Kesehatan. Jakarta. Penerbit EGC

Creswell.J.W, 2010, Research Design: Pendekatan Kualitatif, Kuantitatif dan Mixed. Yogyakarta. Penerbit Pustaka Pelajar.

Danim. S, 2002, Menjadi Peneliti Kualitatif. Bandung. Penerbit CV. Pustaka Setia.

Dawson, C, 2010, Metode Penelitian Praktis: Sebuah Panduan, Yogyakarta. Penerbit Pustaka Pelajar.
Dellitiz, C, et al, 1999, Research Methods in Social Relations, New York, Hold Reinhart and Wilson Inc.

Hadi.Sutrisno, 2001, Metodologi Research. Jilid 3. Yogyakarta. Penerbit Andi Offset.

Heriyanto. A., Sandjaja, 2006, Panduan Penelitian, Jakarta. Penerbit Prestasi Pustaka

Sangaji, E.M., Sopiah, 2010, Metodologi Penelitian: Pendekatan Praktis dalam Penelitian, Yogyakarta. Penerbit Andi Offset.

Saryono,2008, Metodologi Penelitian Kesehatan. Yogyakarta. Mitra Cendikia Press

Sastroasmoro S, Ismael S ,2002, DasarDasar Metodologi Penelitian Klinis. Edisi ke-2. Jakarta: CV. Sagung Seto

Sarwono, J,2006, Metode Penelitian Kuantitatif dan Kualitatif. Yogyakarta: Graha Ilmu.

Sunyoto, Danang, 2012, Prosedur Uji Hipotesis Untuk Riset Ekonomi, Bandung, Penerbit Alfabeta.

Suryabrata, S, 2012, Metodologi Penelitian, Jakarta, Penerbit PT. Rajagrafindo Persada.

Syamsul Hadi, http: Journals.lww.com/academic/fulltec s/2001/09000/problem statemen. Conceptual,frame, work.

Zamzam, Fakhry, 2014, Good Governance Sekretariat DPRD, Yogyakarta, Deepublish. 
2015, Model Penelitian

Kuantitatif, Berbasis SEM-Amos,

Yogyakarta, Deepublish
Penulisan Proposal Tesis,

Palembang, Noer Fikri. 